\title{
ALTERNATIVE DISPUTE RESOLUTION, THE THREAT OF ADVERSE COSTS, AND THE RIGHT OF ACCESS TO COURT
}

\author{
by Shirley Shipman \\ LLB, BCL, M Phil (Oxon), D Phil (Oxon), PCTHE, FHEA
}

CPR 1(4)(2)(e) requires the court to encourage potential litigants to use an ADR procedure where appropriate. The court has adopted a number of means to encourage the use of ADR processes: ranging from education and publicity to more robust approaches such as criticism, court orders and, the ultimate weapon, the threat of an adverse costs award 1. According to the case of Halsey $v$ Milton Keynes General Trust $\mathrm{NHS}_{2}$, it is appropriate to award adverse costs where a successful party at court has unreasonably refused (at the request of the unsuccessful party or the suggestion of the court) to go to mediation. Thus, the successful party may face not only his own costs of the action but also the costs of his defeated opponent. According to Sir Anthony Clarke MR, 'such cases should be very few and far between'3. However, research conducted on two mediation programmes in the Central London County Court suggests that the threat of an adverse costs award acted as an impetus for a number of individuals who took part in a mediation process4. This paper explores the possibility that the court's role in encouraging ADR, at least in relation to the use of adverse costs awards, has the potential to conflict with an individual's right of access to a court (an aspect of the right to a fair trial) under Article 6(1) ECHR.

In this context there are three potential situations where an individual may argue that the Article 6(1) right has been prevented or restricted. This may occur where a) an individual has settled the claim in an ADR procedure and, as a result, is unable to pursue a claim through the courts; b) following an unsuccessful ADR process an individual runs out of funds to advance the claim through the courts; c) an individual has successfully brought or defended the claim through the courts but adverse costs are awarded for unreasonable refusal to undertake an ADR process. In situations a) and b) the allegation would be that the threat of adverse costs led the individual to undertake an ADR procedure and that, as a result, (s)he has been effectively denied the opportunity to pursue the claim through the courts (Golder v United Kingdom, Airey v United Kingdom5) either because of settlement at the ADR procedure or because the individual exhausted funds at that stage. In situation c), the claim would be that the imposition of an adverse costs award has denied the party concerned effective access to the courts (Steel \& Morris v United Kindom6).

\footnotetext{
1 S Shipman 'Court Approaches to ADR in the Civil Justice System' (2006) 25 CJQ 181

2 Halsey v Milton Keynes General Trust NHS [2004] EWCA Civ 576, [2004] 1 WLR 3002 [9]

3 Sir Anthony Clarke MR 'The Future of Civil Mediation' The Second Civil Mediation National Council

Conference, Birmingham 8 May 2008

http://www.judiciary.gov.uk/docs/speeches/mr_mediation conference may08.pdf [19]

4 H Genn, P Fenn, M Mason, A Lane, N Bechai, L Gray, D Vencappa 'Twisting Arms: Court Referred and

Court Linked Mediation Under Judicial Pressure' (Ministry of Justice Research Series 1/07 21 May 2007)

eg Executive Summary iv, 5, 89, 93, 219

5 Golder v United Kingdom Series A No 18 (1975) 1 EHRR; Airey v Ireland Series A No 32 (1979) 2

EHRR 305

6 Steel \& Morris v United Kingdom (Application No 64816/01) 15 February 2005
} 


\section{EFFECTIVE DENIAL OF THE OPPORTUNITY TO PURSUE A CLAIM THROUGH THE COURTS (SITUATIONS A) AND B))}

In raising an Article 6(1) challenge in relation to situations a) and b) an individual would need to address two key questions: first, whether, in undertaking an ADR procedure, (s)he has waived his right of access to a court and, secondly, if not, whether the use of an adverse costs award in this context is within the state's margin of appreciation. In relation to the first issue, the applicant would need to counter two inter-linked arguments: 1) that (s)he has had the opportunity to go to court but has chosen, instead, to make use of an alternative process; and 2) in doing so (s)he has waived his/her right of access to a court. Where an individual has undertaken an ADR procedure, it is difficult to deny that there has been the opportunity to continue the court litigation process. A refusal to undergo an ADR procedure does not preclude the individual from subsequently pursuing the claim through the courts. However, in situations a) and b) it is the very undertaking of the ADR procedure that prevents access to the courts either where the individual reaches a settlement agreement as a result (which is, after all the aim of the ADR process - but in which case proceedings are generally barred) or where the litigant is unable to take no further action due to failure of funds. The key to a successful application here is, therefore, whether the individual has waived his right of access to a court due to submission to an ADR procedure.

\section{A Waiver and the Right of Access to a Court}

There are four criteria to be satisfied in relation to a successful defence of waiver under Article 6(1):

1) the right must be capable of waiver

2) the right must be waived in an unequivocal manner

3) where a waiver is considered unequivocal it must be accompanied by sufficient guarantees commensurate to the importance of the right waived

4) the waiver must not be tainted by constraint

\section{1) The right must be capable of waiver}

The right of access under Article 6(1) is not an absolute right and the ECtHR has recognised that waiver of this right does not offend against the Convention. There is no compulsion for an individual to bring a civil claim through the courts so there can be no difficulty for an individual to choose to take his dispute to an ADR procedure. Indeed the ECtHR has recognised in Deweer $v$ Belgium 7 that there may be 'undeniable advantages for the individual concerned as well as for the administration of justice's in utilising such procedures (although the Court did not enunciate what it perceived those advantages to be).

7 Deweer v Belgium (1980) 2 EHRR 439

8 ibid [49] 
2) The right must be waived in an unequivocal manner

To satisfy this aspect the waiver can be express or tacit. The ECtHR has held that voluntary submission to an ADR procedure amounts to an unequivocal waiver of the right - this does not need to be express, the act of submitting to the process amounts to a tacit waiver (Suovaniemi v Finland9). However, knowledge appears to be an important feature here 10. If an individual is unaware that a settlement reached through an ADR procedure will generally prevent litigation of the same point, then that lack of knowledge may prove fatal to a claim that the right of access to court has been waived.

3) It must be accompanied by sufficient guarantees commensurate to the importance of the right waived

This aspect has received little discussion in the jurisprudence of the ECtHR and hence little guidance is given, either as to what amounts to sufficient guarantees, or as to how to weigh the importance of the Article 6(1) right. In Pfeifer v Austria 11, the ECtHR considered whether an applicant's express waiver of his right to an impartial tribunal was accompanied by sufficient safeguards. There was no legislative provision permitting such waiver, the applicant had been unaccompanied by his legal representative when agreeing to waive this right, and there were no procedural safeguards. The Court held that this violated the applicant's Article 6(1) right. However, the ECtHR have yet to decide whether, given the importance of the right to an impartial tribunal, it is possible for an applicant to waive this right even with appropriate safeguards. By way of contrast, in the Suovaniemi case 12, the Court considered that the fact that the applicants had been represented throughout the arbitration procedure ensured that the waiver of their right to impartial arbitrators by the applicants was accompanied by sufficient guarantees. Whilst, the ECtHR has recognised the fundamental importance of the right of access to court it has also consistently stated that this right is not absolute and is subject to limitations 13 . It would certainly seem unlikely, therefore, that an applicant who has been represented by legal counsel would be able to argue that there have been insufficient safeguards. It would seem appropriate, however, to ensure that case management judges, legal representatives and mediators alike explain the binding effect of an agreement reached through an ADR procedure to ensure that the individuals concerned are aware that reaching such an agreement precludes further recourse to the courts on that issue, especially since lack of knowledge indicates that there is no unequivocal waiver.

\section{4) Absence of Constraint}

The ECtHR has stated that 'too great an importance attaches to 'the right to a court' ... for its benefit to be forfeited solely by reason of the fact that an individual is a party to a settlement reached in the course of a procedure ancillary to court proceedings ... absence

\footnotetext{
9 Suovaniemi v Finland Application No 31737/96 Decision 23 February 1999

10 Colozza v Italy Series A No 89 (1985) [27]-[32]

11 Pfeifer \& Plankl v Austria Series A No 227 (1992)

12 Suovaniemi (n9)

13 Eg Ashingdane v United Kingdom Series A No 93 (1985) 7 EHRR 528 [57]
} 
of constraint is at all events one of the conditions to be satisfied' (Deweer v Belgium) 14 . This aspect is, therefore, a crucial element.

The ECtHR has given little guidance on what amounts to constraint. In the seminal case of Deweer, the applicant was faced with the option of either paying a fine for the alleged offence of over-pricing his meat or with the closure of his business in 48 hours until a criminal hearing to determine his guilt. He paid the fine but as a result had to forego the opportunity to prove his innocence at trial. The Belgian Government argued that $\mathrm{Mr}$ Deweer had waived his right of access to the court through his acceptance of a friendly settlement. However, the Court considered that the prospect of the loss of income due to the closure of his business over possibly several months, together with the consequent difficulties of paying staff and the potential loss of customers, amounted to compelling pressure to settle. Additionally, whilst the applicant had an arguable defence, he faced the prospect of a much higher fine if found guilty at trial.

The ECtHR did not, in the Deweer case, enunciate criteria for assessing constraint and there appears to have been little discussion of this point in subsequent cases. The most significant feature in the Deweer case was the direct and potentially severe effect of the threat of closure. A further feature may have been the immediacy of the threat. However, even if the threat of closure had been for six months' time, arguably there would have been the same potentially severe effects.

The situation in relation to court encouragement to undertake an ADR procedure is different. First, there is no immediate threat to deprive a non-compliant individual of his business if he does not settle the claim. Secondly, the individual is encouraged to undertake an ADR procedure - taking part in the process, whilst clearly aimed at encouraging settlement, is not necessarily going to lead to a settled claim. However, as a result of the case management duty of the courts to encourage parties to undertake an ADR procedure, individuals arguably face two types of pressure: first, authoritative encouragement and secondly, the threat of an adverse costs award.

\section{a) Authoritative Encouragement}

This aspect encompasses advice received from legal representatives (who are themselves open to criticism from the court for failure to pursue this option15) as well as court encouragement. There has been some unresolved debate in the case law as to whether court orders to undertake an ADR procedure could in themselves conflict with an individual's right of access to court16, hence the courts have been careful not to order individuals to attend such processes 17. Despite such caution court encouragement may be robust. For example, an ADR order issued by the Admiralty and Commercial Court

14 Deweer (n7) [49]

${ }_{15}$ Eg Cowl v Plymouth City Council [2001] EWCA Civ 1935, [2002] 1 WLR 803

16 Shirayama Shokusan Co Ltd v Danovo Ltd [2004] 1 WLR 2985; Halsey (n2)

17 Halsey (n2) [9] But see Sir Anthony Clarke MR (n3) [7]-[18]: the Master of the Rolls argues that the point made in Halsey that compulsory mediation orders are contrary to Article 6(1) is likely to be incorrect 
requires parties to take serious steps to resolve their dispute before an ADR panel and to inform the court why those steps have failed if the case does not settle.

Whilst the encouragement of the court may be highly persuasive it would seem unlikely that this on its own would be sufficient to amount to constraint. If an individual refuses to comply with the court's suggestion or order he is not denied from pursuing his claim through the courts 18. However, parties who refuse to undertake ADR procedures where encouraged to do so run the risk of adverse costs.

\section{b) Adverse Costs Award}

According to Halsey v Milton Keynes General Trust NHS 19, it is appropriate for a court to make an adverse costs award where a party has unreasonably refused (at the request of the court or another party) to undertake an ADR procedure. The costs of legal proceedings in this jurisdiction are such that a party may prefer to compromise the claim rather than pursue his legal rights20. The prohibitive nature of the cost of legal proceedings has itself been the subject of challenge before the ECtHR. In such cases the applicant has alleged that the actual or potential costs of litigation have prevented him from either pursuing a claim through the courts or from advancing an effective action 21. It is worth noting at this point that in such a situation the individual concerned has not been refused access to the courts, rather it is the direct or indirect effect of the lack of funds that acts as an impediment to the courts. For example, in Steel \& Morris v United Kingdom 22, the ECtHR found that the applicants had been denied effective access to court where, due to the unavailability of legal aid, they had defended themselves in lengthy defamation proceedings against a large multi-national company. It would seem unlikely that the ECtHR would have less sympathy for an applicant who has been unable to bring his claim at all due to lack of funding than for one who has advanced his cause ineffectively through the courts.

The concern at this point, however, is not with whether a litigant is unable to advance or defend a claim due to lack of funding, but rather with whether a litigant, who undergoes an ADR procedure, may successfully argue that the pressure to undertake such a procedure constitutes constraint, thus countering the potential argument that in compromising the action through an ADR process he or she has waived his right of access to a court. Lack of funds may constitute a significant factor in the pressure faced by individuals to avoid court proceedings, however, the possibility of an adverse costs award increases that pressure. If adverse costs were automatically awarded for refusal to take part in an ADR process it would appear probable that the ECtHR would find, in

\footnotetext{
18 Sir Anthony Clarke (n3) [19]

19 Halsey (n2) [9]

20 For a more in-depth analysis of such cases: S Shipman 'Defamation and Legal Aid in the European Court of Human Rights' (2005) 24 CJQ 23, S Shipman 'Steel \& Morris v United Kingdom: Legal Aid in the European Court of Human Rights' (2006) 25 CJQ 5

21 'Steel \& Morris $v$ United Kingdom: Legal Aid in the ECHR' (n20) 7-12 for an exploration of the distinction between the situation where an applicant has been effectively denied a right of access to court and where an individual has been denied the opportunity to present an effective claim or defence 22 Steel\& Morris (n6)
} 
certain circumstances at least, this threat to constitute constraint: arguably (as in Deweer) such a threat would have direct and potentially severe financial consequences. The consequences would not be as immediate as in the Deweer case, but the costs of legal proceedings may be as severe as losing one's home or one's business.

However, in this context, unlike in the case of Deweer, adverse costs are not awarded automatically but are awarded where the court considers that an individual has unreasonably refused to undertake an ADR procedure. The difficulty for an individual, making the decision to undertake an ADR procedure or to proceed to trial, is that an assessment of whether the refusal would be considered unreasonable at the costs hearing is not straightforward (particularly prior to the trial).

The case of Halsey sets out guidelines for what constitutes unreasonable behaviour. Factors include the nature of the dispute, the merits of the claim, the prospects of success of the ADR procedure, the encouragement of the court, together with issues relating to expense and delay. A number of issues arising from discussion of these factors make it uncertain for individuals to know when their refusal would be considered unreasonable 23 . For example, according to the Halsey guidance, a party's reasonable belief that he has a strong case may be 'sufficient justification for refusing to mediate' 24. However, whether the party's belief in the strength of his case is reasonable is based on an objective assessment following the trial on the merits and, hence, is made with the benefit of hindsight. Parties, prior to the hearing, may find it difficult to have the necessary objectivity. For example, the court held in Burchell v Bullard 25 that the defendant behaved unreasonably in believing his case was so watertight that he need not engage in attempts to settle. This decision was based on judicial assessment of the reasonableness of the defendant's belief with the benefit of hindsight following trial. However, even following success at first instance it is not necessarily clear that the successful party's belief in the strength of his case would be considered reasonable. In Reed Executive $v$ Reed 26 an influential factor in the finding that the defendant had reasonably refused an invitation to mediate the dispute was his reasonable belief in the prospects of success of the appeal27. The belief, with the benefit of hindsight, was held to be justified as the defendant had won his appeal. However, he had been unsuccessful at first instance. It is difficult for parties to proceedings to make objective assessments about the merits of their cases, particularly where emotionally involved or financially dependent on the outcome. A particularly illustrative example is provided by the case of Hurst $v$ Leeming.

In that case a solicitor pursued a claim (described as 'hopeless' by Lightman J) against his legal representative in previous proceedings. Lightman J stated that:

... it is plain that Mr. Hurst has been so seriously disturbed by the tragic course of events resulting from the dissolution of the partnership that his judgement in respect of matters concerning the partnership and partnership action and the conduct of that action on his

23 Discussed in detail in S Shipman (n1)

24 Halsey (n2) [18]

25 Burchell v Bullard [2005] EWCA Civ 358

26 Reed Executive plc v Reed Business Information Ltd [2004] EWCA Civ 887, [2004] 1 WLR 3026

27 ibid [46] 
behalf is seriously disturbed: he is a person obsessed with the injustice which he considers has been perpetrated on him and is incapable of a balanced evaluation of the facts 28

Arguably, if a solicitor (caught as he was in the emotional throes of the life events which led to the court proceedings), is unable to make an objective or realistic assessment of the strength of his claim, how much more difficult is this for a lay person.

This point is further illustrated by the case of Hickman v Blake Lapthorn 29. This was a negligence claim against solicitors and counsel arising from a personal injury case. Both defendants were themselves legal professionals, however, they had significantly different views of the value and strength of the defence. Consequently, the first defendant wished to go to mediation, the second defendant did not, believing that the strength of the defence warranted trial.

There are also difficulties with another aspect of the Halsey guidelines, that is, with assessing the prospects of success of a mediation process. According to Halsey, a party unreasonably refuses to undertake an ADR procedure where that process would have reasonable prospects of success. However, as the Court conceded in that case, 'it may be difficult for the court to decide whether the mediation would have had a reasonable prospect of success' 30 . Arguably, if the court is unable to make that assessment it is also problematic for the party to form an accurate opinion of the prospects of success. The Court offered further comments on this point to the effect that some disputes were more intractable than others and some mediators more skilled than others31. At the stage of choosing whether to go to mediation or run the risk of adverse costs through proceeding to trial the skill of the mediator or the willingness of each party to compromise may not be known.

A further feature indicating unreasonable refusal is that of encouragement of the court. Where the court has encouraged parties to undertake an ADR procedure this may lead to a finding that the refusing party has acted unreasonably. This is particularly the case where the encouragement of the court is robust. Hence, for example, where the court gives an ADR order, a refusing party is likely to face an adverse costs award for refusal. At this point, the pressure to undertake an ADR procedure must be almost irresistible. It is less certain whether a party will be considered to have refused unreasonably where the court adopts a less robust approach. It would seem that the stronger the encouragement the more likely a party will be considered unreasonable for refusal to comply. But since it is a matter degree it is difficult for an individual to assess the weight that will be accorded to this factor in an assessment of unreasonable refusal.

It is clear that there are a number of uncertainties as to when a refusal to undertake an ADR procedure would be considered unreasonable. This uncertainty does create additional pressure. Arguably, the prospect of an adverse costs award (particularly where

\footnotetext{
28 ibid [5]

29 Hickman v Blake Lapthorn [2006] EWHC 12, [2006] 2 All ER (D) 67 (Jan) (QB)

30 Halsey (n2) [27]

31 See on this point: H Genn (n4) Executive Summary, 91, 104, 175
} 
this is accompanied by strong court encouragement) may constitute constraint. The essence of waiver tainted by constraint is that the individual has no real choice as to whether to exercise a particular right. Hence, the waiver of that right can not be considered voluntary. The voluntary character of a decision depends on the level of freedom to choose. To be a valid waiver there must be true choice to concede the particular right. It is arguable that in certain circumstances an individual is denied a true choice in deciding to undertake an ADR procedure rather than proceeding to trial.

\section{B The Margin of Appreciation}

In the Deweer case there was no discussion of whether the state's constraint was justifiable. The case was decided prior to the case of Ashingdane $v$ United Kingdom 32: the case in which the ECtHR introduced the concept of the margin of appreciation into its jurisprudence on Article 6(1). In the event of a finding that the threat or actual award of adverse costs amounts to constraint, it would seem probable, therefore, that the ECtHR would consider whether its use was within the State's margin of appreciation: that is whether the threat of adverse costs pursues a legitimate aim and is a proportionate means of achieving that aim.

\section{1) Legitimate Aim}

In relation to Article 6(1) the ECtHR seldom, if ever, finds that a measure does not pursue a legitimate aim. In the context of civil justice applications, measures with the aim of enabling the general functioning of the civil justice system (for example, in ensuring the efficient use of court resources or for promoting expedition) are considered legitimate 33. Also, measures that restrict an individual's right of access to court with the aim of protecting the rights of interests of others are also considered legitimate 34.

It is certainly arguable that the encouragement of parties to undertake ADR procedures enables the efficient administration of justice. A key objective of the Woolf review of the civil justice system was to improve access to justice. Arguably, use of ADR encourages a more efficient use of court resources. In a system where court litigation is to be viewed as the last resort35, this contributes (alongside other methods encouraging settlement) to an efficient use of court resources, which is designed to ensure that limited court resources are available for those individuals who most need them and, hence, for those individuals access to justice is improved 36. Arguably, access to justice is therefore improved as the courts are not clogged with allegedly unnecessary litigation. However, there is a further sense in which the use of ADR can be said to improve access to justice. This entails understanding justice in a broader sense than that understood when

\footnotetext{
32 Ashingdane (n13) [57]

33 Eg Tolstoy Miloslavsky v United Kingdom Series A No 316-B (1995) 20 EHRR 442 [61]; Perez de Rada Cavanilles v Spain (2000) 29 EHRR 109 [45]; Osu v Italy Application No 36534/97 Judgment 11/07/2002 [32]

34 Stubbings $v$ United Kingdom (1997) 23 EHRR 213 [51]

35 Lord Woolf Access to Justice: Final Report to the Lord Chancellor on the Civil Justice System in England and Wales (HMSO 1996) Overview[9](a)

36 Sir Anthony Clarke MR (n3) [18]
} 
considering access to the courts. On this understanding justice encompasses dispute resolution brought about by alternative means - this may be relational justice (where the parties are able to continue in their relationship due to the compromise and discussion brought about by mediation, for example) or may be due to consumer satisfaction (where, for example, the parties are satisfied that their voice is heard in the process).

The use of an ADR procedure may also be said to protect the interests of other parties in the litigation through, for example, the saving of expense or more speedy resolution of the claim 37.

It appears highly probable that the ECtHR would accept that the threat of adverse costs orders for unreasonable refusal to undertake an ADR procedure, together with court encouragement of such procedures, pursue legitimate aims. The more interesting point for discussion is whether the Court would view its use as proportionate.

\section{2) Proportionate Means}

In the context of a claim that a measure has restricted an applicant's right of access to court under Article 6(1), the ECtHR assesses whether there the measure adopted to achieve the particular aim is proportionate by balancing the general interest (for example, in enabling the general administration of justice) against the individual's interest in vindicating his right before the courts. In relation to whether a measure is proportionate to achieve its aim, the ECtHR scrutiny in relation to measures adopted to enable the general administration of justice or to protect the interests of others appears to be variable. The most relevant cases to consider here are those where an applicant has been unable to bring or defend a claim for financial reasons (for example, due to the imposition of court fees or for refusal to hear an appeal without payment into court of the judgment debt).

According to the ECtHR, administration of justice concerns may justify imposing financial restrictions on the right of access to court. For example, there is no requirement to provide free legal proceedings 38 and strict limitations may be put on access to appellate courts 39 but, it should be noted that the ECtHR rarely finds that refusal to hear a claim or an appeal due to applicant's inability to comply with a financial requirement is within a State's margin of appreciation. According to the ECtHR, restrictions of a financial nature should be subject to particularly rigorous scrutiny40. For example, in certain Polish cases, where the applicant has been unable to have a court hearing due to an inability to pay the court fee, the ECtHR has adopted such a strict level of scrutiny that it has examined the fact findings of the national court and found that refusals to exempt payment have been based on an erroneous finding of facts 41 . The issue, according to the ECtHR, is that the

37 But see S Shipman (n1) for discussion on whether mediation saves expense (199-201) and expedites cases (202-204)

38 Kreuz v Poland Reports of Judgments and Decisions 2001-VI [59]

39 Podbielski \& PPU Polpure v Poland Application No 39199/98 Judgment 26/07/2005 [65]

40 Ibid [65]

41 ibid [67]-[68], Teltronic-CATV v Poland Application No 48140/99 Judgment 10/01/2006 [53]-[60],

Kreuz (n38) [61]-[67] 
Convention is intended to guarantee rights that are practical and effective, not theoretical and illusory 42.

In relation to the threat of adverse costs for unreasonable refusal to undertake an ADR procedure there are certain differences from the cases heard relating to financial restrictions. First, the threat of adverse costs is not a direct financial impediment which acts as a barrier to entry to the courts as, for example, in the Polish cases. In those cases the aim, however, of the fee was not to prevent entry but rather to derive income for the State or to cover the costs of proceedings. In the case of the threat of adverse costs, this measure is designed to discourage entry. The aim is to stop individuals from using the courts and to push them towards ADR. Arguably, this threat acts as a fee to the extent that a potential litigant, facing the prospect of an adverse costs award following trial, is in reality posed with the threat that if he or she chooses to enter the court system he or she may have to pay a significant price to do so (albeit in terms of an adverse costs award made in favour of the opposing party rather than as a payment to the state for the privilege of using its resources). Secondly, the threat of adverse costs is imposed not to generate income for the State but rather to protect the interests of the other party who has been to put to the expense of going to court when (s)he would have been prepared to undertake an ADR procedure. However, there are other ways of protecting this interest (for example, a Part 36 offer). Moreover, whilst this measure may serve to protect the interests of an opposing party, particularly where that party has expressed a desire to undertake an ADR procedure rather than pursue the claim or defence through the courts, the threat also serves to protect the interests of the state, in particular the objective of viewing litigation as a last resort in order to ensure the efficient use of limited court resources. The more cases that can be turned away from the courts the fewer court resources the state has to provide.

The ECtHR makes its assessment of whether a financial restriction has a disproportionate impact on an applicant in the light of the circumstances of the case: in particular, the applicant's ability to pay appears to be the most significant factor but the ECtHR also considers the stage of proceedings at which the financial restriction was imposed 43 . This latter aspect has a more variable influence. Where the restriction prevents a first instance hearing it appears that the ECtHR has always found this is in violation of Article 6(1). It is less certain that the ECtHR will find there has been a violation where the restriction imposed denies the applicant an appellate hearing.

Hence, in deciding whether the threat of an adverse costs award is disproportionate, the financial circumstances of the applicant (including funding possibilities provided that these are not hypothetical44) are likely to be influential, particularly since the costs of litigation in this jurisdiction are so high. It is more difficult to assess the impact of the stage of proceedings at which the threat is imposed since parties may be encouraged or requested to undertake ADR at various stages of proceedings. Whilst the threat of an adverse costs order will most likely occur prior to the first instance hearing and, hence, in

42 Kreuz (n38) [57]

43 ibid [60], Polpure (n39) [64]

44 Teltronic-CATV (n41) 
situations a) and b) the applicant will not have that hearing, the threat is indirect, rather than direct. As already mentioned, however, this threat is designed to discourage access to a court and it may be that the ECtHR will find that such impact is disproportionate.

A further factor that the ECtHR may consider, should it be required to consider a claim of this nature, is whether the merits of the case or its prospects of success have been considered. According to the ECtHR it adopts a particularly rigorous scrutiny where such restrictions (at least at the appellate stage) are completely unrelated to the merits of the claim or the prospects of the success 45 . Where the State is able to demonstrate that the merits of the claim and the prospects of its success on appeal have been considered then the ECtHR appear more likely to accept that the financial restriction is proportionate 46. Where the national court has encouraged parties to undertake an ADR procedure it is possible, in deciding whether such encouragement is appropriate (in line with its case management duty47), that the court has considered the merits of the case (although a more significant consideration at that stage may be the prospects of success of the ADR procedure, rather than the prospects of success at trial). But an adverse costs award may also be awarded where it is the opposing party who has requested an ADR procedure. Where the court has not suggested this course of action then there would be no need for it to consider the merits of the case. The important point is that at the stage when the party makes the decision whether to undertake an ADR procedure or run the risk of an adverse costs award the strength of the case may not be known. Where there has been no suggestion that an individual is vexatious or that a statement of case should be struck out as disclosing no reasonable grounds for the action or there should be summary judgment for no reasonable prospects of success, then it would seem that there are no grounds for suggesting that an individual should not advance his or her case through the courts. This point would seem pertinent to the fact that an adverse costs award will only be imposed where an individual's refusal to undertake an ADR procedure is unreasonable. Unreasonable refusal in this context cannot be equated to unreasonable behaviour in pursuing the action.

It is uncertain how the ECtHR would respond to the fact that an individual is unable with certainty to predict when an adverse costs award would be awarded for refusal to undertake an ADR procedure. But the ECtHR may consider that the uncertainty of the risk may lead a vulnerable party to undertake an ADR procedure when his or her strong preference may have been to go to court. Hence, whilst it is not certain that the ECtHR would find the threat of an adverse costs award to be disproportionate, it is not beyond the realms of possibility. The recent case of Stankov $v$ Bulgaria 48 adds further weight to the prospect that the ECtHR may find a violation of Article 6(1).

\section{DENIAL OF EFFECTIVE ACCESS TO THE COURT (SITUATION C)}

\footnotetext{
45 Polpure (n39) [65]

46 Tolstoy Miloslavsky (n33) [63]

${ }_{47}$ CPR 1.4(2)(e)

48 Stankov v Bulgaria Application No 68490/01 12 July 2007
} 
In the Stankov case, the State imposed a fee of $4 \%$ of the value of the part of the claim on which the applicant failed. This was imposed at the end of the hearing (as would be the situation with an adverse costs award). According to the ECtHR, this rendered the right of access to court illusory and theoretical since it wiped out a significant proportion of the damages won49. The Court reiterated that Article 6(1) is intended to guarantee rights that are practical and effective 50. The Court accepted that the imposition of the fee was compatible with the good administration of justices1 but in relation to assessing the proportionality of the restriction the Court commented that there had been no suggestion that the applicant's claim was vexatious or exaggerated 52 and that the claimant could not, therefore, be criticised for making the claim he did53. The Court was concerned that the fee was imposed at the end of the trial rather than prior to the hearing and, therefore, considered that this removed the cautioning effect which there would have been had this been imposed at the outset54. However, in this case, a further influential factor was the fact that the $4 \%$ fee was automatically imposed where a claimant failed in part, or all, of his claim. Hence, there was no judicial discretion and no opportunity to waive or reduce the fees 55 .

This case is relevant to a claim that the imposition of an adverse costs award, following success at trial, for unreasonable refusal to undertake an ADR procedure amounts to a restriction on the right of access to court. In such a situation the adverse costs award would be imposed also at the end of the trial. However, unlike in the Stankov case, there is judicial discretion as to whether to make such an award since it is imposed only for unreasonable refusal. However, it must be feasible that the ECtHR would similarly consider that such an award amounted to a violation of Article 6(1), where the applicant's claim was not vexatious or that the claimant could not be criticised for bringing or defending the claim, particularly if the costs award effectively wiped out the value of the claim and, hence, rendered his right illusory and theoretical.

\section{Conclusion}

The study of relevant ECtHR jurisprudence suggests that it is possible, in certain circumstances, that the ECtHR may find that the threat or actual imposition of an adverse costs award amounts to a violation of an individual's right of access to court under Article 6(1). This conclusion is enhanced by the fact that if the rhetoric about the advantages of ADR is accurate, then education and use over time ought to be sufficient to promote greater use. It is worth noting also that research conducted in the Central London County Court suggests that where individuals feel pressurised into mediation, there is less likely to be a settlement as a result of the mediation56. The use of a measure

\footnotetext{
49 Ibid [54]

50 Ibid

51 Ibid [67]

52 Ibid [61]

53 Ibid [62]

54 Ibid [65]

55 Ibid [66]

56 H Genn (n4) Executive Summary and 90-93
} 
that adversely impacts on an individual, and is not a particularly effective way of achieving a specific aim, is arguably disproportionate. 